\title{
NEPHROPROTECTIVE ACTIVITY OF ETHANOL EXTRACT OF KIRINYUH (CHROMOLAENA ODORATA L) IN GENTAMICIN INDUCED NEPHROTOXICITY IN WISTAR RATS
}

\author{
KENI IDACAHYATI, LUSI NURDIANTI, SILVI SIPTANUL HUSNI, FIRMAN GUSTAMAN, WINDA TRISNA \\ WULANDARI
}

Departemen of Clinical Pharmacy and Pharmacology, Bakti Tunas Husada Institute of Health Science, Tasikmalaya, Indonesia Email: keniida@stikes-bth.ac.id

Received: 25 Sep 2020, Revised and Accepted: 16 Oct 2020

\section{ABSTRACT}

Objective: The global prevalence of Chronic Kidney Disease (CKD) was 9.1\% (697.5 million cases). Chronic kidney disease can occur, one of which is caused by drug nephrotoxicity. Nephrotoxicity remains major problem for its effective long-term clinical use. Gentamicin is known to cause many morphologic, metabolic and functional alterations in the kidney and the specificity of gentamicin nephrotoxicity is related to its accumulation in the renal proximal convoluted tubules leading to tubular necrosis. Nephrotoxicity can be prevented by nephroprotective by giving antioxidants. Kirinyuh leaves (Chromolaena odorata L.) has potential as a nephroprotective because it contains chemical compounds that have antioxidant activity.

Methods: Wistar rats as many as 25 animals were divided into five groups, namely the normal control negative control (gentamicin $60 \mathrm{mg} / \mathrm{kg}$ BW rat), and kirinyuh leaf extract at a dose of 225,450 and $675 \mathrm{mg} / \mathrm{kg}$ BW treatment was carried out for $10 \mathrm{~d}$. Serum creatinine and urea levels were evaluated along with histopathological investigation in various experimental groups of rats. Data analysis using the One Way Anova test and continued LSD test.

Results: Serum creatinine was a significant difference between groups $\mathrm{P}=0.000(\mathrm{P}<0.05)$. The results of LSD analysis on creatinine levels showed a significant difference between the normal group and the negative group $(\mathrm{P}=0.00)$; negative group to dose group $1(\mathrm{P}=0.020)(\mathrm{P}<0.05)$; dose $2(\mathrm{P}=$ $0.005)(\mathrm{P}<0.05)$; and dose $3(\mathrm{P}=0.000)(\mathrm{P}<0.05)$. Dose 3 had the lowest creatinine level compared to other dose groups.

Conclusion: Serum creatinine level at dose 675 significantly changes compare by a negative group of other dose groups. Renal histopathology results showed that the group with a dose of $450 \mathrm{mg} / \mathrm{BW}$ of rats had the lowest necrosis rate compared to the negative control group and other dose groups.

Keywords: Chronic kidney disease, Gentamycin, Nephroprotective, Kirinyuh

(C) 2021 The Authors. Published by Innovare Academic Sciences Pvt Ltd. This is an open access article under theCCBYlicense (https://creativecommons.org/licenses/by/4.0/) DOI: https://dx.doi.org/10.22159/ijap.2021.v13s3.11 Journal homepage: https://innovareacademics.in/journals/index.php/ijap

\section{INTRODUCTION}

Chronic kidney disease (CKD) is kidney damage and a decrease in Glomerular Filtration Rate (GFR) of less than $60 \mathrm{ml} / \mathrm{min} / 1.73 \mathrm{~m}^{2}$ for a minimum of 3 mo [1]. The prevalence of CKD globally is $13.4 \%$, and $48 \%$ of people have decreased kidney function but do not need hemodialysis. Then as many as $96 \%$ of people experience kidney damage, but they are not aware of it [2]. In Indonesia, CKD increased prevalence in 2013, from $2 \%$ to $3.8 \%$ in 2018 [3]. Chronic kidney disease can be caused by drug nephrotoxicity. Gentamicin is an aminoglycoside antibiotic commonly used in clinical practice for the treatment of life-threatening Gram-negative bacterial infections can be restricted due to profound nephrotoxicity side effects [4]. Nephrotoxicity is a condition characterized by changes in cell morphofunctional such as impaired protein synthesis, increased lipid peroxidation process, decreased urine concentration capacity, tubular proteinuria, lowering of GFR and mitochondrial damage [5]. The mechanism of gentamicin causes nephrotoxicity by directly or indirectly activating the intrinsic apoptotic pathway by reducing the production of ATP and causing oxidative stress by increased free radical species such as superoxide anion $\left(\mathrm{O}_{2^{-}}\right)$, hydroxide anion $\left(\mathrm{OH}^{-}\right.$ ), and hydrogen peroxide $\left(\mathrm{H}_{2} \mathrm{O}_{2}\right)$ in mitochondrial cells in the renal cortex. Mitochondrial DNA (mtDNA) is susceptible to oxidative damage by Reactive Oxygen Species (ROS), which continually increase within the mitochondrial matrix to cause cell death or necrosis. Gentamicin stimulates expression of inducible nitric oxide synthase (iNOS) and NO production in the isolated glomerulus, and mesangial cells contraction could be mediated by several mechanisms secretion of platelet-activating factor (PAF). The increase in available NO during the oxidative stress can react with superoxide anion, and peroxynitrite is created. The created peroxynitrite is further creating nitrosative stress and cytotoxicity [6]. Oxidative stress is a predisposing factor and direct cause of various disorders in both human and animals, including renal [7]. Nephrotoxicity can be prevented by the presence of nephroprotective adding natural antioxidants. Kirinyuh leaves have a high antioxidant activity that is with a concentration inhibitor value $\left(\mathrm{IC}_{50}\right)$ of $9.5671 \mathrm{ppm}$ and has an antioxidant capacity of $49.037 \%[8,9]$. The purpose of this study was to determine the antioxidant activity of kirinyuh leaves as a nephroprotective.

\section{MATERIALS AND METHODS}

Material

Chemical materials

Hydrochloric acid, 96\% ethanol, gentamicin, formaldehyde, picric acid, glacial acetic acid, $10 \% \mathrm{NaOH}, \mathrm{Mg}$, Mayer reagent, Wagner, Lieberman-Burchard, $\mathrm{FeCl}_{3}$, creatinine and urea reagent kit, $\mathrm{CMC}$ $1 \%$, $\mathrm{NaCl} 0,9 \%$, aqua dest. Formaldehyde 4\%, xylol paraffin, Hematoxylin Eosin, $\mathrm{NaOH}$, hydrochloric acid, sulfuric acid.

\section{Plant materials}

Kirinyuh Leaves were obtained from Cicarulang Village, Singaparna City, Tasikmalaya, West Java, Indonesia. They were determined by Herbarium Plant Taxonomy Laboratory of Biology Department, Faculty of Mathematics and Natural Sciences, Padjadjaran University, Bandung.

\section{Extraction}

Kirinyuh leaves were collected and washed, cut, dried and powdered. He extracts were prepared by macerating a weighed amount $1000 \mathrm{~g}$ with $96 \%$ ethanol. The results of the extraction obtained as much as $3.5 \mathrm{~L}$ liquid extract then concentrated and received as much as 46 grams of extract. Rendement extract obtained was $4.6 \%$.

\section{Phytochemical screening methode}

\section{Detection of flavonoids}

Simplicia the powder was put into a test tube filled with water, then heated, then filtered, the filtrate obtained added to obtain 
magnesium powder. Add a solution of alcohol and hydrochloric acid (1: 1). The mixture shaken vigorously, the formation of a red, yellow or orange filtrate that can be drawn by amyl alcohol, indicating the presence of flavonoids [10].

\section{Detection of tannins-polyphenols}

Simplicia the powder is put into a test tube filled with water, heat the test tube over a water bath, then it is filtered hot. The filtrate is divided into two parts; drop the reagent iron (III) chloride in the first part, the formation of a blue-black colour indicates the presence of tannins and polyphenols. The filtrate was added with $1 \%$ gelatin in the second part, the shape of a white precipitate showed positive content of tannins [10].

\section{Detection of saponin}

Simplicia the powder is extracted using water, then heated in a water bath, then filtered. The filtrate obtained is cooled, then the filtrate is shaken vigorously for a few minutes, then dilute hydrochloric acid added; the presence of $1 \mathrm{~cm}$ foam indicates the presence of saponin compounds [10].

\section{Detection of steroids}

The simplicia extract is added with ether, then evaporated until dry. After that, the Lieberman-Burchard reagent is dropped on the residue; the formation of purple colour indicates that it is positive for steroid-triterpenoid [10].

\section{Detection of monoterpenoid-sesquiterpenoid}

The simplicia powder was extracted using ether, the extract obtained was evaporated to dryness, Vanillin-H2SO4 reagent or sulfate reagent was added to the residue, the presence of anisaldehyde-monoterpenoid and sesquiterpenoid compounds was shown by the formation of colours [10].

\section{Experimental animals}

The experimental protocol was approved by the Ethics Committee Bakti Tunas Husada Institute of Health Science No: 015/06/kepkbth/2020. Twenty-five Wistar rat weighing 150-200 g were obtained and acclimatized in one week. They were maintained under standard housing conditions with free excess to a standard diet and water ad libitum during the experiment. Animals were divided randomly into five groups of 5 animals each namely normal group was administered at standard diet, and water ad libitum, negative control group was administered gentamicin intraperitoneal injection $60 \mathrm{mg} / \mathrm{kg} \mathrm{BW}$, dose 1 group was administered gentamicin $60 \mathrm{mg} / \mathrm{Kg}$ BW intraperitoneal injection for $10 \mathrm{~d}$ and treated with $225 \mathrm{mg} / \mathrm{Kg}$ BW intraperitoneal injection rat of kirinyuh leaves extract, for $10 \mathrm{~d}$, dose 2 group was administered gentamicin $60 \mathrm{mg} / \mathrm{Kg} \mathrm{BW}$ intraperitoneal injection for $10 \mathrm{~d}$ and treated with $450 \mathrm{mg} / \mathrm{Kg} \mathrm{BW}$ rat of kirinyuh leaves extract for $10 \mathrm{~d}$, and dose 3 group was administered gentamicin $60 \mathrm{mg} / \mathrm{kg}$ BW intraperitoneal injection for $10 \mathrm{~d}$ and treated with $675 \mathrm{mg} / \mathrm{Kg}$ BW rat of kirinyuh leaves extract for $10 \mathrm{~d}$.

\section{Biochemical analysis}

The rats were anaesthetized with diethyl ether, and 2-3 $\mathrm{ml}$ of blood samples was collected by orbital venous sinus. The samples were allowed to clot and centrifuged at $3000 \mathrm{rpm}$ at $30^{\circ} \mathrm{c}$ for 10 min, and the separated serum was used for the following biochemical estimations using commercially available kits: creatinine FS (Diasys Diagnostic System Germany Ref 131019910021) and urea FS (Diasys Diagnostic System Germany Ref 117119910021).

\section{Histopathology of rat kidney}

After blood sampling, all the animals were sacrificed by cervical dislocation under deep anesthesia. And subjected to a complete necropsy followed by histopathology. The rat kidneys were identified and carefully dissected out for histopathological examination. After rinsing in normal saline, sections were taken from each harvested kidney, fixed in $10 \%$ formalin, dehydrated in gradual ethanol (50-100\%), cleared in xylene, and embedded in paraffin wax. The $5-6 \mu \mathrm{m}$ sections were prepared using a rotary microtome and stained with haematoxylin and eosin dye for microscopic observation of the histopathological changes [7].

\section{Statistical analysis}

One-way analysis of variance (ANOVA) was used to determine significant intergroup differences of each parameter. A p-value $<0.05$ was considered statistically significant.

\section{RESULTS AND DISCUSSION}

Flavonoids and polyphenols are compounds contained in kirinyuh leaves that can provide antioxidant activity (table 1).

Table 1: Phytochemical screening of kirinyuh leaves simplicia and extract

\begin{tabular}{lll}
\hline Phytochemical & Simplicia & Extract \\
\hline Flavonoids & + & + \\
Polyphenols & + & + \\
Tannins & - & - \\
Saponin & - & - \\
Steroids & + & + \\
Sesquiterpenoids & + & + \\
Monoterpenoid & + & + \\
Quinone & + & - \\
\hline
\end{tabular}

Flavonoids can reduce free radicals and also as antioxidants [11]. The mechanism of flavonoids as antioxidants can form a defence system to prevent free radicals from damaging the body [11]. Many flavonoids are excellent free radical scavengers due to their strong abilities as hydrogen or electron donors [12]. Phenol compounds also have antioxidant activity because they can reduce free radicals by donating electrons through the hydrogen atom of the hydroxyl group [13]. The results of creatinine levels in the normal, negative, dose 1 , dose 2 , and dose 3 groups can be seen in table 2 .

Table 2: Creatinin levels of serum after administered of ethanol extract of kirinyuh

\begin{tabular}{lll}
\hline Group & Average of creatinine level \pm SD (mg/d) & Significant $(\mathbf{P}<\mathbf{0 , 0 5})$ \\
\hline Normal & $0.754 \pm 0.08$ & 0.000 \\
Negative & $3.772 \pm 1.59$ & \\
Dose 1 & $2.028 \pm 1.15$ & \\
Dose 2 & $1.704 \pm 1.04$ & \\
Dose 3 & $1.082 \pm 0.34$ & \\
\hline
\end{tabular}


Table 2 showed that serum creatinine was a significant difference between groups $\mathrm{P}=0.000(\mathrm{P}<0.05)$. The results of LSD analysis on creatinine levels showed a significant difference between the normal group and the negative group $(\mathrm{P}=0.00)$; negative group to dose group 1 $(\mathrm{P}=0.020)(\mathrm{P}<0.05)$; dose $2(\mathrm{P}=0.005)(\mathrm{P}<0.05)$; and dose $3(\mathrm{P}=0.000)$ $(\mathrm{P}<0.05)$. Dose 3 had the lowest creatinine level compared to other dose groups. Creatinine is the waste product produced by the breakdown of muscle phosphate keratin that is constantly produced by the body depending on muscle mass and actively is excreted unchanged by the kidneys secreted by the proximal tubular cells. Its level rises in the blood if there is a deficiency in kidney filtration capacity, suggesting remarkable damage to the nephron by measuring the glomerular filtration rate [14]. The results of urea levels in the normal, negative, dose 1 , dose 2 , and dose 3 groups can be seen in table 3 .

Table 3: Urea levels of serum after administered of ethanol extract of kirinyuh

\begin{tabular}{lll}
\hline Group & Average of Urea level+SD (mg/d) & Significant (P<0,05) \\
\hline Normal & $16.08 \pm 3.82$ & 0.000 \\
Negative & $72.80 \pm 29.88$ & \\
Dose 1 & $114.54 \pm 45.84$ & \\
Dose 2 & $66.68 \pm 24.35$ & \\
Dose 3 & $31.30 \pm 6.97$ & \\
\hline
\end{tabular}

Table 3 showed that urea levels were a significant difference between normal, negative, dose 1 , dose 2 , and dose 3 groups $\mathrm{p}=$ $0.000(\mathrm{P}<0.05)$. Based on the results of LSD analysis on serum urea levels in the dose 3 group showed a significant difference with a negative control with a significance value $\mathrm{p}=0.001 \quad(\mathrm{P}<0,05)$. Kirinyuh leaves extract dose of $675 \mathrm{mg} / \mathrm{kg}$ BW was the lowest serum urea level compared to the other dose groups and was the closest to the normal urea level of the normal control group. Urea is filtered across the glomerulus and enters the proximal tubule. The concentration of urea in the ultrafiltrate is similar to plasma, so the amount of urea entering the proximal tubule is controlled by the GFR [15].

Urea and creatinine are metabolic waste products that are excreted by the kidneys through urine, and only a small amount is left in the blood. If there is a disruption in kidney function, then there is an increase in these two parameters [16].

Table 4: Percentage rate of cell necrosis

\begin{tabular}{ll}
\hline Group & Percent of necrosis (\%) \\
\hline Normal & 6 \\
Negative & 12.35 \\
Dose 1 & 7.95 \\
Dose 2 & 6.90 \\
Dose 3 & 8.25 \\
\hline
\end{tabular}

Histopathological studies also reveal the protective effect of kirinyuh leaves extracts on the kidney of gentamicin-treated rats. Based on the results of histopathology prove that the administration of toxic doses of gentamicin can cause kidney damage characterized by the percentage of cell necrosis in kidney organs increasing higher than a normal rat. Gentamicin-associated nephrotoxicity was associated with glomerular and tubular damage which was observed by the destruction of the tubular lumen [17].

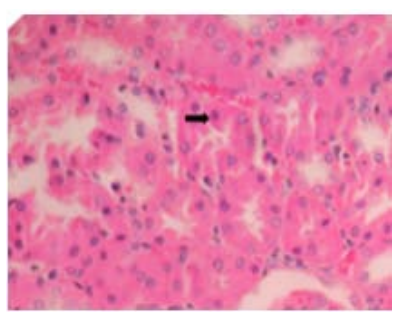

a

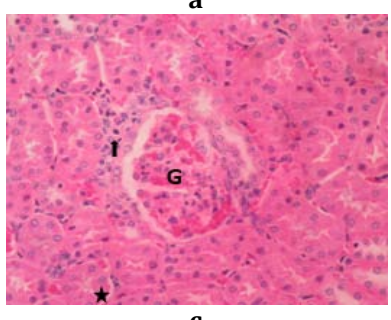

c

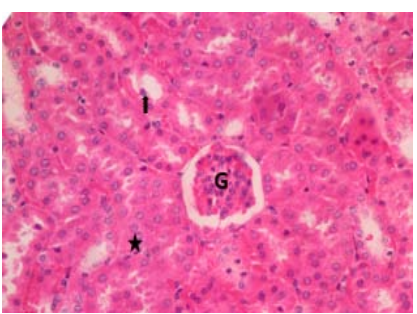

b

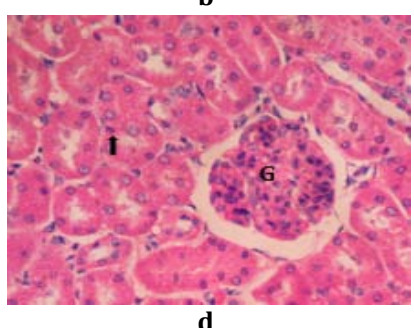

d

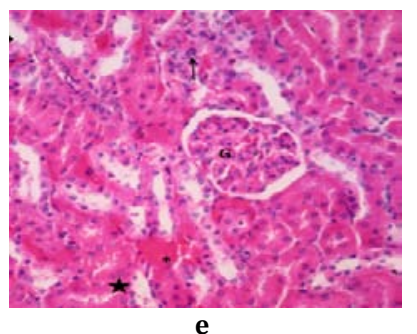

Fig. 1: histopathology of kidney rat $a=$ normal group; $b=$ negative group; $c=$ dose $1 ; d=d o s e ~ 2 ; e=d o s e ~ 3$ 
The toxic effect of gentamicin might be due to the development of free radicals that may cause renal impairment [6]. reduction in antioxidant defence mechanisms, acute tubular necrosis, and glomerular congestion [18]. Gentamicin-associated nephrotoxicity was associated with glomerular and tubular damage which was observed by the destruction of the tubular lumen [17]. The rat kidney histopathology results in kirinyuh administration inhibit necrosis by decrease the percentage of cell necrosis in the renal. The antioxidant activity of flavonoids and polyphenols contained in kirinyuh leaves can neutralize free radicals [11]. Flavonoids can reduce the number of lesions formed by increasing the amount of exogenous antioxidants in the body to compensate for endogenous antioxidants. Flavonoids are known to have natural antioxidant activity that can neutralize or capture free radicals [19]. Flavonoids also act as a secondary antioxidant defence system in plant tissues exposed to different abiotic and biotic stresses. Flavonoids are located in the nucleus of mesophyll cells and within centers of ROS generation. Mechanisms of antioxidant action suppression of ROS formation either by inhibition of enzymes or by chelating trace elements involved in the free radical generation and scavenging ROS [20].

\section{CONCLUSION}

Serum creatinine level at dose 675 significantly changes compare by a negative group of other dose groups. Renal histopathology results showed that the group with a dose of $450 \mathrm{mg} / \mathrm{BW}$ of rats had the lowest necrosis rate compared to the negative control group and other dose groups.

\section{ACKNOWLEDGEMENT}

The authors would like to thank the Ministry of Research and Technology/National Research and Innovation Agency of Republic Indonesia and STIKes Bakti Tunas Husada Tasikmalaya

\section{FUNDING}

Nil

\section{AUTHORS CONTRIBUTIONS}

All the authors contributed equally.

\section{CONFLICT OF INTERESTS}

Authors declare no conflict of interest.

\section{REFERENCES}

1. Milik A, Hrynkiewicz E. KDIGO 2012 clinical practice guideline for the evaluation and management of chronic kidney disease. KDIGO 2013;19:4477-83.

2. Nathan R Hill, Samuel T Fatoba, Jason L Oke, Jennifer A Hirst CAO, Daniel S. Lasserson1 FDRH, 1. Prevalence of chronic kidney disease: a systematic review and meta-analysis. Clin Nephrol 2016;71:244-54.

3. Indonesian Ministry of Health. Indonesia Basic Health Research 2018. Indonesia Ministry of Health; 2018. p. 1-100. Available from: http://www.depkes.go.id/resources/download/infoterkini/hasil-riskesdas-2018.pdf [Last accessed on 15 Aug 2020]
4. Adil M, Kandhare AD, Dalvi G, Ghosh P, Venkata S, Raygude KS, et al. Ameliorative effect of berberine against gentamicininduced nephrotoxicity in rats via attenuation of oxidative stress, inflammation, apoptosis and mitochondrial dysfunction. Ren Fail 2016;38:996-1006.

5. El Badwi AOB, EHAG. Haemato-biochemical effects of aqueous extract of khaya senegalensis stem bark on gentamicin-induced nephrotoxicity in wistar rats. J Biol Sci 2012;12:361-6.

6. Randjelovic P, Veljkovic S, Stojiljkovic N, Sokolovic D, Ilic I. Gentamicin nephrotoxicity in animals: current knowledge and future perspectives. EXCLI J 2017;16:388-99.

7. Gheith I, El-Mahmoudy A. Novel and classical renal biomarkers as evidence for the nephroprotective effect of Carica papaya leaf extract. Biosci Rep 2018;38:1-10.

8. Saputra A, Gani A, Erlidawati E. Antioxidant activity of siam gulma (Chromoleana Odorata L.) using the 1,1-diphenyl-2picrylhydrazil method. J IPA Pembelajaran IPA 2017;1:131-42.

9. Her N, Parnanto R, Setyowati R, Utami R. Nur her riyadi parnanto 1), Rini Setyowati 1), Rohula Utami 1); 2013. p. VI.

10. Buckley JP. Pharmaceutical Sciences (Np). Science (80-) 1966;151:874-5.

11. Sarian MN, Ahmed QU, Mat So'Ad SZ, Alhassan AM, Murugesu S, Perumal V, et al. Antioxidant and antidiabetic effects of flavonoids: a structure-activity relationship based study. Biomed Res Int 2017. DOI:10.1155/2017/8386065

12. Zhang H, Li X, Wu K, Wang M, Liu P, Wang X, et al. Antioxidant activities and chemical constituents of flavonoids from the flower of Paeonia ostii. Molecules 2017;22:5.

13. Mathew S, Abraham TE, Zakaria ZA. Reactivity of phenolic compounds towards free radicals under in vitro conditions. J Food Sci Technol 2015;52:5790-8.

14. Ehsani V, Amirteimoury M, Taghipour Z, Shamsizadeh A, Bazmandegan G, Rahnama A, et al. Protective effect of hydroalcoholic extract of pistacia vera against gentamicininduced nephrotoxicity in rats. Ren Fail 2017;39:519-25.

15. Weiner ID, Mitch WE, Sands JM. Urea and ammonia metabolism and the control of renal nitrogen excretion. Clin J Am Soc Nephrol 2015;10:1444-58.

16. Nerdy N, Ritarwan K. Hepatoprotective activity and nephroprotective activity of peel extract from three varieties of the passion fruit (Passiflora sp.) in the albino rat. Maced J Med Sci 2019;7:536-42.

17. Sonkar N, Ganeshpurkar A, Yadav P, Dubey S, Bansal D, Dubey $N$. An experimental evaluation of the nephroprotective potential of Butea monosperma extracts in albino rats. Indian J Pharmacol 2014;46:109-12.

18. Randjelovic P, Veljkovic S, Stojiljkovic N, Velickovic L, Sokolovic $\mathrm{D}$, Stoiljkovic $\mathrm{M}$, et al. Protective effect of selenium on gentamicin-induced oxidative stress and nephrotoxicity in rats. Drug Chem Toxicol 2012;35:141-8.

19. Geng R, Ma L, Liu L, Xie Y. Influence of bovine serum albuminflavonoid interaction on the antioxidant activity of dietary flavonoids: new evidence from electrochemical quantification. Molecules 2019;24:70.

20. Kumar S, Pandey AK. Chemistry and biological activities of flavonoids: an overview. Sci World J 2013. DOI:10.1155/2013/162750 